\title{
The Extent of Practicing Crisis Management by Jordanian Secondary School Principals in the Light of the Contemporary Educational Challenges
}

\author{
Heba Hasan Omar Doghmosh \\ Prof. Ahmad Mohammad Battah
}

\begin{abstract}
The present study aimed to explore the extent of practicing crisis management by Jordanian secondary school principals in the light of the contemporary educational challenges. The study's population consists from the principals and teachers who at Jordanian secondary schools. The sample consists from 1000 principals and teachers who work at Amman. To meet the study's goals, a descriptive approach was adopted. It was found that the extent of practicing crisis management by Jordanian secondary school principals is moderate in the light of the contemporary educational challenges. It was found that practicing crisis management by Jordanian secondary school principals in the light of the contemporary educational challenges is highly significant. Therefore, it's necessary to identify the contemporary educational challenges and the crisis derived from such challenges. The researchers suggested several recommendations. For instance, they recommend activating the role of crisis management in the light of the contemporary educational challenges.
\end{abstract}

Keywords: crisis management, Jordanian secondary school principals, contemporary educational challenges

DOI: $10.7176 / \mathrm{JEP} / 11-15-16$

Publication date:May $31^{\text {st }} 2020$

\section{Introduction}

Many scientific, intellectual and technological changes and developments occurred to the world. There are several difficulties and challenges derived from such changes and developments. In order to handle such difficulties and challenges by the management of institutions, such management started practicing crisis management.

Similar to other institutions, educational institutions in Jordan were influenced by changes and developments. The management of these institutions found it necessary to address the challenges they have been facing. They are responsible for utilizing the available financial and human resources with exerting the least amount of effort and dedicating the least amount of time. They are responsible for managing risks and overcoming the barriers hindering them from meeting the intended goals (Abu Farwa, 1997).

In the light of the challenges faced by schools, new obligations are assigned to the principals. Carrying out these obligations shall enable principals to lead their subordinates effectively. It shall enable principals to improve the organizational performance. It shall enable principals todeal with sudden emergency and unusual situations. Managing such situation is called (crisis management).

Crisis management refers to a systematic administrative operations that involve preventive measures and procedures that aim at avoiding a crisis. These measures and procedures aim at reducing the severity of the consequences of the crisis if experienced. They aim at achieving the positive outcomes as much as possible (AlJahni, 2010).

When shedding a light on the reality of secondary schools in Jordan, it can be noticed that crisis management is practiced at those schools in a daily manner. However, the leaders at those schools aren't not capable of managing crises effectively. For instance, most crises are managed by those leaders based on their own visions and unplanned responses (Al-Khazouz, 2007).

The incapability of those leaders to manage crises effectively became clearer when several new challenges emerged. Such challenges include: (school violence, teacher strike, terrorism, the urgent need to develop teachers \& etc..). It was found that leaders of Jordanian secondary schools show a poor performance in managing those crises. In addition, those leaders show a poor performance in reducing the severity of the consequences resulting from those crises. Al-Nawayseh (2006) suggests that most school principals in Jordan lack expertise in managing crises. He adds that few principals in Jordan sought developing themselves in the way of managing crises. He adds that many principals in Jordan don't acknowledge the existence of a crisis. He adds that many principals in Jordan lie through suggesting that there isn't any crisis faced. He adds that some principals in Jordan hold others responsible for the occurrence of the crisis. The latter principals do that in order not to be held accountable for the occurrence of the crisis.

The poor performance of Jordanian school leaders in managing crises leads to experiencing other crises. It has many consequences. It negatively affect the school and its performance. In the light of the aforementioned information, managing crises in the light of the contemporary educational challenges is very significant. Therefore, the present study aimed to explore the extent of practicing crisis management by Jordanian secondary school 
principals in the light of the contemporary educational challenges.

\section{Statement of the Problem:}

Secondary schools are influenced by the changes that have been occurring to the world. Some of those changes positively affected those schools and other changes negatively affected those school. The management of schools realized that consequences of those changes and the crises associated with those changes. Therefore, they realized that it's necessary to manage the crises derived from those changes effectively. It should be noted that school principals play a significant role in managing such crises. In order for schools principals to manage crises effectively, they must set effective plans and possess the required expertise in the field of crises management. One of the researchers of the present study works in the educational field. Due to the nature of her job, she realized that the majority of school principals in Jordan show a poor performance in addressing the educational challenges and managing the crises derived from such challenges. In addition, most the relevant literature indicate that this is true. Therefore, the problem of the present study is represented in the following question: (What's the extent of practicing crisis management by Jordanian secondary school principals in the light of the contemporary educational challenges?)

\section{The Study's Questions}

The present study aimed to answer the following questions:

Q.1. What's the extent of practicing crisis management by Jordanian secondary school principals in the light of the contemporary educational challenges from the perspective of teachers and principals?

Q.2. What's the extent of significance of practicing crisis management by Jordanian secondary school principals in the light of the contemporary educational challenges from the perspective of teachers and principals?

\section{The Study's Objectives:}

The present study aimed to explore the extent of practicing crisis management by Jordanian secondary school principals in the light of the contemporary educational challenges from the perspective of teachers and principals. It aimed to explore the extent of significance of practicing crisis management by Jordanian secondary school principals in the light of the contemporary educational challenges from the perspective of teachers and principals.

\section{The Study's Significance:}

The results of the present study are beneficial for the officials working at the Jordanian Ministry of Education. They are beneficial for the secondary school principals and teachers in Jordan. They are beneficial for the researchers in the field of crisis management. In addition, the present study offers a theoretical framework about crisis management.

\section{The Definition of Terms: \\ The study's terms are defined below: \\ Crisis management:}

Abu Naser (2008: 134) defines it as a scientific strategy that aims at preventing crises in schools and improving the school performance. He adds that crisis management aims at ensuring the safety of the school staff and addressing weaknesses and faults.

The researchers define crisis management as: an administrative task that is carried out by the school principals. Carrying out this task effectively requires having planning, organization, and guidance skills. It aims at avoiding crises or reducing the severity of crises in case they occurred. It aims at reducing the severity of the consequences of the crises. In the present study, the performance of school principals in managing crises is assessed through distributing questionnaire forms to secondary school principals and teachers in Jordan.

Secondary school: It refers to the school that secondary school students are enrolled at. There are various streams in secondary schools. Students decide which stream they want to enroll at based on their capabilities and interests. Secondary schools meet the occupational and scientific needs of the members of the Jordanian society. They enable students to enroll in higher education institutions when finishing school. They enable students to join the labor market when finishing school (http://www.moe.gov.jof).

\section{Contemporary educational challenges:}

They refer to problems, barriers of difficulties that may significantly affect the capabilities of the education institutions or hinder them from meeting their goals. They may increase the severity of the problems they are facing (Zain Al-Deen, 2013).

\section{The Study's Limits:}

The present study targets secondary school principals and teachers in Amman, Jordan. It was conducted during 
the first semester of the scholastic year (2019/2020).

\section{Theoretical framework:}

Through this part, the researchers shed a light on several references related to crisis management.

\section{Crisis management:}

Many rapid developments have occurred to the crisis management field. Through crisis management, leaders and managers can manage internal and external crises in various institutions, including in educational institutions.

Abu Al-Ola (2012: 150) defines crisis management as an administrative approach that aim at dealing with crises through employing scientific methods. Such methods include: planning, organization, guidance and following up. They include: forming crisis management teams, carrying out assessment, using information and communication systems and leading others.

Devlin (2007:1) suggest that crisis management refers to the process of using measures for addressing the problems derived by the crisis.

After identifying the meaning of crisis management in general, it is necessary to shed a light on crisis management in the educational field. The management of educational crisis seeks identifying and examining the reasons of experiencing the educational crisis. It seeks taking preventive measures for handling any sudden emergency situation. It seeks managing any educational crisis through utilizing all the available resources and opportunities (Hamdoonah, 2006, 10).

Chase $(1999$, p.5) defines the management of educational crisis as measures taken by the educational institution in order to reduce the probabilities of experiencing an educational crisis.

Based on these definitions, it can be noticed that there systematic and scientific operations that can be carried out by school management for managing any crisis. Therefore, school principals should acquire knowledge about such operations. They shouldn't take measures for managing crises based on their unplanned responses. In fact, they must manage crises through carrying out systematic and scientific operations. These operations include (planning, organization, guidance, following up, forming crisis management teams, leading others, using information and communication system, making decisions during crisis, carrying out assessment.

\section{The role of the school principal in managing crises at school}

The school principal plays a vital role in the school. He/she is considered responsible before students, officials and parents for anything that occur in the school. For sure, managing crises is considered one the essential tasks of the school principal. This tasks is assigned to the school principal, because he/she is the one who's capable the most to influence teachers. It is assigned to the school principal, because he/she is the one who's concerned the most in meeting the intended goals.

There are various strategies that can be implemented by school principals for managing crises. However, there are specific common foundations that regulate the process of managing crises. All school principals must take these foundations into consideration when managing crises. Such foundations enable principals to identify their duties in the process of crisis management. They include the following ones: (Al-Jahni, 2010)

1) The school principal must have much knowledge about administrative issues. For instance, he/she must have much knowledge about planning, organization, guidance, and assessment

2) The school principal must have much knowledge about crisis management in general and crisis management in schools in particular. He/she must have much knowledge about the methods of crisis management.

3) The school principal must be capable of utilizing the available information which is related to school management.

4) The school principal must be capable of forming a crisis management team whose members are highly qualified.

Al-Khudairi (2002) suggests that school principals must have excellent capabilities to form excellent relationships with the members of the crisis management team. He adds that school principals must have excellent imaginative and planning capabilities (Al-Khudairi, 2002)

School principals must have excellent capabilities to influence and motivate employees through using creative methods. That shall enable principals to manage crises effectively. School principals must have excellent capabilities to set applicable visions for managing crises. These visions must be delivered to the staff in the institution. School principals must have excellent capabilities in setting goals and making plans that are based on these goals. They must have capabilities in implementing such plans effectively (Odeh, 2008; Al-Khudairi, 2002; Al-Jahni, 2010).

The contemporary educational challenges:

There is a debate between scholars on the relationship between crises and challenges. Some scholars suggest that crises and challenges have the same meaning. They suggest that a challenge involve several crises. Nataj (2010) 
suggests that a challenge refers to a set of crises that are experienced in all the areas locally and globally. He adds that the society must address these challenges. Al-Musleehi $(1998,77)$ suggests that a challenge refers to any qualitative or quantitative analysis change or transformation that is associated with new demands or requirement that are difficult to meet by the society. Therefore, the society must address this challenge through taking the necessary measures.

Regarding the educational challenges, they refers to problems and issues that hinder the educational process during the contemporary age locally, regionally and globally. The severity of these challenges increase throughout time. That is attributed to the increasing number of rapid transformations. It's attributed to the increasing number of technological developments. It is attributed to the increasing rapid changes that occur to social and economic areas. It's attributed to the fact that the severity of problems of all types increase throughout time (Al-Tnatawi, 2000).

\section{The present study shed a light on the following educational challenges: \\ First: School violence:}

Violence refers to a behavior that aims at causing harm to others. This behavior isn't accepted socially. School violence is considered very serious problem. That's because it hinders the management of schools from meeting the intended academic and educational goals. School violence may include: verbal, physical and psychological violence. The types of such violence in Jordanian schools may include:

-Violence by a student against another student

-Violence by a student against a teacher

-Violence by a teacher against a student (Al-Khawaldeh and Al-Zyoodi, 2012).

\section{Second: Social media:}

Having technical and scientific advancements led to the emergence of tools and technologies that made the world a small village. Such technologies include: social media. Social media can be used through having an internet connection. It allows its users to exchange photos, videos, information and etc. with each other (Al-Harbi, 2015).

The disadvantages of social media include the following ones:

a) Improper images and videos may be posted through social media

b) Electronic thefts may be committed through social media

c) Plagiarism may be committed through social media

d) Terrorist ideas may be promoted through social media among students by extremists

e) Sitting for a long time while surfing social media pages shall negatively affect students' health

f) The information posted on social media isn't reliable (Al-Sharhan, 2000).

Third: Teacher strike

The teacher strike is a very significant challenge that faced the Jordanian educational system. This challenge emerged recently. Its emergence may be attributed to establishing the teachers association in Jordan. This association aims at protecting the teachers' rights and improving the teachers' status in society. It employs several methods for meeting its goals. Such methods include: the teacher strike.

The researchers of the present study define strike as the refusal to work in an intentional and collective manner. This refusal aims to force the employer to meet the employees' demands. Many educators suggest that teacher strike negatively affects the students' academic achievement. They believe that teacher strike isn't a proper methods for claiming for the teachers' rights. That is because the teacher strike hinders the educational process and causes a mess in society. It's because the teacher strike leads to having a delay in implementing the syllabus. Other scholars suggest that the teacher strike is a proper method for claiming for the teachers' rights and improving the teachers' status.

The teacher strike emerged recently. However, preventive measures and procedures must be carried out to ensure that it won't occur in the future. Therefore, the officials at the Ministry of Education, mangers at the directorates of education, the principals and teachers themselves must be involved in such measures and procedures.

\section{The Previous Studies:}

Through this section, the researchers reviewed the relevant studies that are either conducted in Arabic or English languages.

-The Studies that are conducted in English Language:

Halaq (2011) conducted a study titled (The role of public secondary school principals in making plans for handling the educational crises: A field study in the schools located in Damascus). To meet the study's goals, the researcher adopted a descriptive analytical approach. The study's sample consists from all the public secondary school principals in Damascus. To be specific, it consists from 172 female and male principals. It was found that there are statistically significant differences between the respondents' attitudes which can be attributed to the years of experience. The latter differences are for the favor of the ones who have more than 20 years of experience. It was 
found that there are statistically significant differences between the respondents' attitudes which can be attributed to the academic qualification. It was found that the public secondary school principals don't play a significant role in making plans for handling the educational crises.

Al-Habees (2015) aimed to explore the effectiveness of the strategies adopted by public secondary school principals in Jordan for managing crises and natural disasters. To meet the study's goals, a descriptive analytical approach was adopted. A historical approach was adopted too. The study's population consists from all the public secondary school principals in Salt, Jordan. It consists from 636principals. A random stratified sample was selected. It consists from 200 principals. It was found that the strategies adopted by public secondary school principals in Jordan for managing crises and natural disasters are effective. It was found that there isn't any statistically significant difference between the respondents' performance levels in managing crises which can be attributed to(gender, experience, or academic qualification).

Battah (2016) conducted a study titled (A proposed vision for managing crises by public secondary school principals in Kuwait). He aimed to explore the extent of implementing strategies by those principals for managing crises. He aimed to provide a proposed vision for managing the crises in public secondary schools in Kuwait from the perspective of principals. He aimed to explore the impact of (gender and academic qualification) on that. To meet the study's goals, a descriptive approach was adopted. The population consists from all the public secondary school principals. It consists from 120 female and male principals. The sample consists from all the members of the population. That's because the population size is small. It was found that extent of prevalence of crises in public secondary schools in Kuwait is moderate. It was found that the extent of implementing strategies by those principals for managing crises is low. It was found that there isn't any statistically significant difference between the respondents in terms of the strategies adopted for managing crises which can be attributed to gender or academic qualification.

Al-Khamees (2019) conducted a study titled (the reality of making decisions by female secondary school leaders for managing crises in schools in Al-Qusaim). To meet the study's goals, a descriptive approach was adopted. A survey was used. The population consists from 189 female secondary school leaders and 26 school supervisors. The sample consists from the whole population. It was found that the reality of making decisions by female secondary school leaders for managing crises in Al-Qusaimis ranked high. It was found that the severity of the difficulties facing female secondary school leaders in Al-Qusaimis moderate. It was found that there isn't any statistically significant difference between the respondents' attitudes towards the latter reality which can be attributed to experience and academic qualification. It was found that there is a statistically significant difference between the respondents' attitudes towards the latter reality which can be attributed to job for the favor of school supervisors.

\section{-Studies written in English language:}

Liming (2010) aimed to explore the most important crises facing public secondary school principals in Manchester, United Kingdom. The sample consists from 24 female and male principals. The latter researcher aimed to explore whether there are differences between the respondents' attitudes which can be attributed to (gender, academic qualification, or experience). It was found that public secondary school principals face problems related to students, teachers, local environment, and educational system. The severity of those problems is moderate. It was found that there are statistically significant differences between the respondents in terms of the problems facing them. These differences are attributed to gender for the favor of males. It was found that there isn't any statistically significant difference between the respondents in this regard which can be attributed to experience or academic qualification.

Peterson (2012) aimed to explore the work-related pressures and the administrative crises faced by secondary school principals in Iowa. The study's sample consists from 120 female and male principals of various school stages. It was found that the severity of the work-related pressures faced by secondary school principals is very high. It was found that the severity of the administrative crises faced by secondary school principals is moderate. The most important problems facing school principals include: the lack of resources and the high work load. It was found that there isn't any statistically significant difference between the respondents' attitudes which can be attributed to gender. It was found that there is a statistically significant difference between the respondents' attitudes which can be attributed to experience. The latter difference is for the favor of the ones who have less experience. It was found that there is a statistically significant difference between the respondents' attitudes which can be attributed to the school stage. The latter difference is for the favor of intermediate school principals.

Cole (2015) conducted a study titled (Evaluation of crisis Management Plan: An Analysis of Primary Schools in Jamaica). He aimed to explore the significance of the crisis management plans from the perspective of primary school principals in Jamaica. He aimed to explore the principals' capability to handle violence in their schools. He aimed to assess the school measures that aim at handling such crisis. An analytical approach was adopted. 10 primary school principals in Jamaica were sampled. It was found that the principals are capable of managing crises. Those principals have expertise about the way of handling violent acts in their schools. It was found that principals 
believe that crisis management plans are considered very important. The principals also believe that having an effective crisis management plan requires having leaders of high performance

Comments on the Previous Studies:

The aforementioned studies differ in terms of the approach. Some studies adopt an analytical approach. As for the present study, it adopts a descriptive approach. Many of those studies shed a light on crisis management in educational institutions. Some of those studies were conducted in Jordan and other studies were conducted outside Jordan. For instance, the study of Al-Habees (2015) was conducted in Salt. As for the present study, it was conducted in Jordan. It sheds a light on crisis management.

The aforementioned studies differ in terms of the sample. Some of those studies sampled secondary school principals and teachers. Other studies sampled school supervisors. The data collection methods used by the aforementioned studies include: interview, questionnaire, and observation. As for the present study, it uses a questionnaire to collect data.

The aforementioned studies assisted the researchers in selecting the population, reviewing the theoretical framework and developing the instrument.

The aforementioned studies shed a light on several subjects. The researchers of the present study found that none of those studies shed a light on the relationship between crisis management and contemporary educational challenges. That distinguish the present study from the aforementioned studies.

\section{Methodology:}

The researchers adopted a descriptive approaches for meeting the study's goals. A questionnaire was developed to identify the extent of practicing crisis management by Jordanian secondary school principals in the light of the contemporary educational challenges from the perspective of teachers and principals. This study was conducted through two stages:

The first stage: Theoretical data was collected about crisis management. That was done through reviewing references and periodicals and surfing the web.

The second stage: The researchers explored reality and collected data about it.

The Study's Population:

The study's population consists from all the public and private secondary school principals and teachers in Jordan during the scholastic year (2019/2020). It consists from 1562 female and male principals.

The Study's Sample:

A purposive sample was selected from secondary schools in Amman. It was selected from five directorates of education. These directorates are: the directorates of (Qasabet Amman, Al-Jame'a, Al-Qwaismeh, Marka, and Na'oor). The sample consists from 200 female and male principals and 800 female and male teachers. Table (1) presents information about the sample:

Table (1): Distribution of the sample in accordance with the directorates of education

\begin{tabular}{|c|c|c|c|c|c|c|c|c|c|c|c|c|}
\hline \multirow{3}{*}{$\begin{array}{l}\text { Directorate } \\
\text { of education }\end{array}$} & \multicolumn{6}{|c|}{ Public schools } & \multicolumn{6}{|c|}{ Private schools } \\
\hline & \multicolumn{3}{|c|}{$\begin{array}{l}\text { Secondary } \\
\text { principals }\end{array}$} & \multicolumn{3}{|c|}{$\begin{array}{l}\text { Secondary } \\
\text { teachers }\end{array}$} & \multicolumn{3}{|c|}{$\begin{array}{l}\text { Secondary } \\
\text { principals }\end{array}$} & \multicolumn{2}{|c|}{$\begin{array}{l}\text { Secondary } \\
\text { teachers }\end{array}$} & school \\
\hline & Male & Female & Total & Male & Female & Total & Male & Female & Total & Male & Female & Total \\
\hline $\begin{array}{l}\text { Qasabet } \\
\text { Amman } \\
\text { Directorate }\end{array}$ & 18 & 20 & 38 & 72 & 80 & 152 & 2 & 13 & 15 & 8 & 52 & 60 \\
\hline $\begin{array}{l}\text { Al-Jame'a } \\
\text { Directorate }\end{array}$ & 11 & 8 & 19 & 44 & 32 & 76 & 5 & 15 & 20 & 20 & 60 & 80 \\
\hline $\begin{array}{l}\text { Al- } \\
\text { Qwaismeh } \\
\text { Directorate }\end{array}$ & 13 & 12 & 25 & 52 & 48 & 100 & 1 & 9 & 10 & 4 & 36 & 40 \\
\hline $\begin{array}{l}\text { Marka } \\
\text { Directorate }\end{array}$ & 18 & 23 & 41 & 72 & 92 & 164 & 2 & 8 & 10 & 8 & 32 & 40 \\
\hline $\begin{array}{l}\text { Na'oor } \\
\text { Directorate }\end{array}$ & 12 & 5 & 17 & 48 & 20 & 68 & $\mathbf{0}$ & 5 & 5 & $\mathbf{0}$ & 20 & 20 \\
\hline Total & 72 & 68 & 140 & 288 & 272 & 560 & 10 & 50 & 60 & 40 & 200 & 240 \\
\hline
\end{tabular}

Source: The records at the Ministry of Education (This data was obtained in pursuant to an authorization by the University of Jordan) 


\section{The Study's Instrument}

To meet the study's goals, a questionnaire was developed. It was developed based on the relevant previous studies and aforementioned literature. The initial version of the questionnaire consists from 51 items. It sheds a light on three areas.

The five point Likert scale was adopted. It sheds al light on the reality of practicing crisis management by Jordanian secondary school principals in the light of the contemporary educational challenges. The criteria adopted for classifying means were set as follows:

(The highest value- the least value)/ the number of the required criteria $=$ the interval

$(5-1) / 3=1.33$

Thus, the interval is 1.33

High: 5-3.68

Moderate: $2.34-1.33$

Low: 2.33 or less

\section{Validity of the Instrument}

Content validity was measured. That was done through passing the initial version of the questionnaire to 11 experts. Those experts are faculty members. They were selected from public and private Jordanian universities. They were asked to assess the questionnaire in terms of clarity, relevancy and language. Based on the experts' opinion, the questionnaire consists from 49 items. The questionnaire sheds a light on 3 areas. These areas are:

1)-The meaning of crisis management (5 items)

2)-The stages of crisis management and the principals' capability to manage crises (31 items)

$3)$ - crisis management in the light of the contemporary educational challenges (13 items).

\section{Reliability of the Instrument}

The reliability of the instrument was measured through calculating Pearson correlation coefficient values. The total Pearson correlation coefficient value is 0.86 . The Pearson correlation coefficient values are within the range of (0.85-0.82). The total Cronbach coefficient value is 0.90 . The Cronbach coefficient value are within the range of 0.86-0.89. Table (2) presents these values

Table (2): The Cronbach coefficient values and the Pearson correlation coefficient values

\begin{tabular}{|l|l|l|l|}
\hline No. & Items & The Pearson correlation coefficient value & The Cronbach coefficient value \\
\hline 1 & $(36-1)$ & 0.85 & 0.86 \\
\hline 2 & $(49-37)$ & 0.82 & 0.89 \\
\hline & Total & 0.86 & \\
\hline
\end{tabular}

\section{Results and Discussion:}

\section{Results related to the first question}

Q.1. What's the extent of practicing crisis management by Jordanian secondary school principals in the light of the contemporary educational challenges from the perspective of teachers and principals?

To answer the first question, means and standard deviations were calculated for the areas. That was done to explore the reality of practicing crisis management by Jordanian secondary school principals in the light of the contemporary educational challenges from the perspective of teachers and principals. The results in this regard are presented below:

Table (3): Means and standard deviations for the reality of practicing crisis management by Jordanian secondary school principals in the light of the contemporary educational challenges from the perspective of teachers and principals

\begin{tabular}{|l|l|l|l|l|l|}
\hline No. & Area & Mean & Std. & Rank & Level \\
\hline 1. & Meaning of crisis management & 3.85 & 0.96 & 1 & High \\
\hline 2. & $\begin{array}{l}\text { The stages of crisis management and the } \\
\text { principals' capability to manage crises }\end{array}$ & 3.75 & 0.87 & 2 & High \\
\hline 3. & $\begin{array}{l}\text { Crisis management in the light of the } \\
\text { contemporary educational challenges }\end{array}$ & 3.17 & 0.86 & 3 & Moderate \\
\hline 4. & Total & 3.62 & 0.72 & & Moderate \\
\hline
\end{tabular}

Based on table (3), the reality of practicing crisis management by Jordanian secondary school principals in the light of the contemporary educational challenges from the perspective of teachers and principals is ranked moderate. That is because total mean is 3.62. The total standard deviation is 0.72 . The means are within the range of 3.85-3.17. The (Meaning of crisis management) is ranked high. The mean of the latter area is 3.85 and the standard deviation of the latter area is 0.96 . The (The stages of crisis management and the principals' capability to manage crises) is ranked second. The mean of the latter area is 3.75and the standard deviation of the latter area 
is 0.87 . The (Crisis management in the light of the contemporary educational challenges) is ranked third. The mean of the latter area is 3.17 and the standard deviation of the latter area is 0.86 .

Means and standard deviations are calculated for each area of the study's areas. The detailed results of each area are presented below:

First: The meaning of crisis management

Table (4): Means and standard deviations for the meaning of crisis management

\begin{tabular}{|l|l|l|l|l|l|}
\hline \multicolumn{1}{|c|}{ No. } & \multicolumn{1}{|c|}{ Area } & \multicolumn{1}{|c|}{ Mean } & \multicolumn{1}{|c|}{ Rank } & \multicolumn{1}{c|}{ Level } \\
\hline 3 & Distinguishing between the types of crises & 3.90 & 1.00 & 1 & High \\
\hline 5 & Realizing the meaning of crisis management & 3.88 & 1.05 & 2 & High \\
\hline 2 & $\begin{array}{l}\text { Distinguishing between crises and other similar } \\
\text { terms (e.g. disaster, conflict, and problem) }\end{array}$ & 3.88 & 1.10 & 2 & High \\
\hline 4 & $\begin{array}{l}\text { Realizing the reasons behind the occurrence of } \\
\text { crises }\end{array}$ & 3.85 & 0.99 & 4 & High \\
\hline & $\begin{array}{l}\text { Having the capability to trace the stages of the } \\
\text { crisis lifecycle }\end{array}$ & 3.75 & 1.06 & 5 & High \\
\hline
\end{tabular}

Based on table (4), the (meaning of crisis management) is ranked high. That's because the overall mean is 3.85. The total standard deviation is 0.96 . The means in this table are within the range of (3.75-3.90). The mean of sub-area No. (3) is 3.90 which is high \&ranked first. The latter sub-area is represented in the following: (Distinguishing between the types of crises). The mean of sub-area No. (4) is 3.75 which is high \& ranked last.The latter sub-area is represented in the following:: (Having the capability to trace the stages of the crisis lifecycle).

Second: The stages of crisis management and the principals' capability to manage crises

Table (5): Means and standard deviations for the reality of the stages of crisis management and the principals' capability to manage crises

\begin{tabular}{|c|l|l|l|l|c|}
\hline No. & Area & \multicolumn{1}{|c|}{ Mean } & Std. & Rank & Level \\
\hline 1. & $\begin{array}{l}\text { Crisis management before the occurrence } \\
\text { of the crisis }\end{array}$ & 3.81 & 0.95 & 1 & High \\
\hline 2. & $\begin{array}{l}\text { Crisis management during the occurrence } \\
\text { of the crisis }\end{array}$ & 3.77 & 0.90 & 2 & High \\
\hline 3. & $\begin{array}{l}\text { Crisis management after the occurrence of } \\
\text { the crisis }\end{array}$ & 3.72 & 0.90 & 3 & High \\
\hline & Total & 3.75 & 0.87 & & High \\
\hline
\end{tabular}

Based on table (5), the reality of the stages of crisis management and the principals' capability to manage crises are ranked high. That is because the overall mean is 3.75 which is high. The overall standard deviation is 0.87. The means are within the range of 3.72-3.81. The mean of sub-area No. (1) is 3.81 which is high and ranked first. The latter sub-areais represented in the following: (Crisis management before the occurrence of the crisis). The mean of sub-area No. (3) is 3.72 which is high and ranked last. The latter sub-area area is represented in the following: (Crisis management after the occurrence of the crisis)

Third: Crisis management in the light of the contemporary educational challenges

Table (6): Means and standard deviations for the reality of the crisis management in the light of the contemporary educational challenges

\begin{tabular}{|l|l|l|l|l|l|}
\hline No. & \multicolumn{1}{|c|}{ Area } & Mean & Std. & Rank & Level \\
\hline 1. & ethical challenges & 3.42 & 0.98 & 1 & Moderate \\
\hline 2. & electronic challenges & 3.23 & 0.98 & 2 & Moderate \\
\hline 3. & educational challenges & 2.85 & 1.24 & 3 & Moderate \\
\hline & Total & 3.17 & 0.86 & & Moderate \\
\hline
\end{tabular}

Based on table (6), the reality of the crisis management in the light of the contemporary educational challenges is ranked moderate. That's because the total mean is 3.17 which is moderate. The total standard deviation is 0.86 . The means are within the range of 3.42-2.85. The mean of the first sub-area is 3.42 which is moderate and ranked first. The latter area is represented in (ethical challenges). The mean of the third sub-area is 3.42 which is moderate and ranked last. The latter area is represented in (educational challenges).

\section{Results related to the second question:}

Q.2. What's the extent of significance of practicing crisis management by Jordanian secondary school principals in the light of the contemporary educational challenges from the perspective of teachers and principals?

To answer the second question, means and standard deviations were calculated. That was done to explore the significance of practicing crisis management by Jordanian secondary school principals in the light of the contemporary educational challenges from the perspective of teachers and principals. The results in this regard are 
presented below:

Table (7): Means and standard deviations for the significance of practicing crisis management by Jordanian secondary school principals in the light of the contemporary educational challenges from the perspective of teachers and principals

\begin{tabular}{|l|l|l|l|l|l|}
\hline No. & \multicolumn{1}{|c|}{ Area } & \multicolumn{1}{|c|}{ Std. } & Rank & Level \\
\hline 1. & $\begin{array}{l}\text { The stages of crisis management and the } \\
\text { principals' capability to manage crises }\end{array}$ & 4.29 & 0.57 & 1 & High \\
\hline 2. & Meaning of crisis management & 4.29 & 0.60 & 1 & High \\
\hline 3. & $\begin{array}{l}\text { Crisis management in the light of the } \\
\text { contemporary educational challenges }\end{array}$ & 4.05 & 0.79 & 2 & High \\
\hline & Total & 4.23 & 0.55 & & High \\
\hline
\end{tabular}

Based on table (7), the overall mean of (the significance of practicing crisis management by Jordanian secondary school principals in the light of the contemporary educational challenges) is high. That's because the overall mean is 4.23. The overall standard deviation is 0.55 . The means are within the range of (4.05-2.29). The means of the sub-areas: (stages of crisis management and the principals' capability to manage crises) and (Meaning of crisis management) are the same (i.e. 4.29). This mean is high and ranked first. The mean of the sub-area(crisis management in the light of the contemporary educational challenges) is 4.05 which is high and ranked last.

The researchers presented below the results related to the significance of practicing crisis management by Jordanian secondary school principals in the light of the contemporary educational challenges. They are presented in accordance with each sub-area:

1)-The stages of crisis management and the principals' capability to manage crises

Table (8): Means and standard deviation for the significance of the stages of crisis management and the principals' capability to manage crises

\begin{tabular}{|l|l|l|l|l|c|}
\hline No. & Area & \multicolumn{1}{|c|}{ Mean } & Std. & Rank & Level \\
\hline 1. & $\begin{array}{l}\text { Crisis management before the occurrence } \\
\text { of the crisis }\end{array}$ & 4.31 & 0.64 & 1 & High \\
\hline 2. & $\begin{array}{l}\text { Crisis management during the occurrence } \\
\text { of the crisis }\end{array}$ & 4.29 & 0.64 & 2 & High \\
\hline 3. & $\begin{array}{l}\text { Crisis management after the occurrence of } \\
\text { the crisis }\end{array}$ & 4.28 & 0.62 & 3 & High \\
\hline & Total & 4.29 & 0.57 & High \\
\hline
\end{tabular}

The means are within the range of 4.28-4.31. The overall mean is 4.29 which is high. The overall standard deviation is 0.57 . The mean of the first sub-area is 4.31 , which is high \& ranked first. The latter sub-area is represented in (crisis management before the occurrence of the crisis). The mean of the third sub-area is 4.28 which is high $\&$ ranked last. The latter sub-area is represented in (crisis management after the occurrence of the crisis)

The meaning of crisis management

Table (9):Means and standard deviations for the significance of the (meaning of crisis management)

\begin{tabular}{|l|l|l|l|l|l|}
\hline No. & Area & Mean & Std. & Rank & Level \\
\hline 2 & Distinguishing between the types of crises & 4.33 & 0.75 & 1 & High \\
\hline 5 & $\begin{array}{l}\text { Realizing the meaning of crisis } \\
\text { management }\end{array}$ & 4.31 & 0.75 & 2 & High \\
\hline 1 & $\begin{array}{l}\text { Distinguishing between crises and other } \\
\text { similar terms (e.g. disaster, conflict, and } \\
\text { problem) }\end{array}$ & $\begin{array}{l}\text { Realizing the reasons behind the } 4.29 \\
\text { occurrence of crises }\end{array}$ & 0.78 & 3 & High \\
\hline 3 & $\begin{array}{l}\text { Having the capability to trace the stages of } \\
\text { the crisis lifecycle }\end{array}$ & 4.24 & 0.74 & 4 & High \\
\hline & Total & 4.29 & 0.60 & High \\
\hline
\end{tabular}

Based on table (9), the mean of the significance of the (meaning of crisis management)is 4.29 which is high. The total standard deviation is 0.60 . The means are within the range of 4.24-4.33.

The mean of sub-area No. (2) is 4.33 which is high and ranked first. The latter sub-area is represented in the following: (Distinguishing between the types of crises). The mean of sub-area No. (3) is 4.24 which is high and ranked first. The latter sub-area is represented in the following: (Having the capability to trace the stages of the crisis lifecycle).

Crisis management in the light of the contemporary educational challenges 
Table (10): Means and standard deviations for the significance of the (Crisis management in the light of the contemporary educational challenges)

\begin{tabular}{|l|l|l|l|l|l|}
\hline No. & Area & Mean & Std. & Rank & Level \\
\hline 1 & Ethical challenges & 4.18 & 0.82 & 1 & High \\
\hline 2 & Electronic challenges & 4.02 & 0.86 & 2 & High \\
\hline 3 & Educational challenges & 3.95 & 1.06 & 3 & High \\
\hline & Total & 4.05 & 0.79 & & High \\
\hline
\end{tabular}

This area consists from 3 sub-areas. The means are within the range of 3.95-4.18. The overall mean is 4.05 which is high. The overall standard deviation is 0.79 . The mean of the first sub-area is 4.18 which is high and ranked first. The latter sub-area is represented in (ethical challenges). The mean of the third sub-area is 3.95 which is high and ranked last. The latter area is represented in (Educational challenges).

\section{Discussion}

The reality of practicing crisis management by Jordanian secondary school principals in the light of the contemporary educational challenges is ranked high. The mean of the first area (i.e. the meaning of crisis management) is high. That may be attributed to the principals' possession of much knowledge about crisis management. Such knowledge include: (knowledge about the meaning of crisis management, knowledge about the reasons of crises, \& knowledge about the crisis lifecycle).

Regarding the mean of the second area (i.e. the stages of crisis management and the principals' capability to manage crises), it's divided into three sub-areas. These sub-areas are: (crisis management before the occurrence of the crisis, crisis management during the occurrence of the crisis, \& crisis management after the occurrence of the crisis). It was found that the mean of the (crisis management before the occurrence of the crisis) is higher than the means of the other sub-areas. That may be attributed to the principals' high awareness about the significance of managing crises and taking preventive measures against crises. Regarding the mean of (crisis management during the occurrence of the crisis), it is high. That indicates that principals have the skills needed for managing crises through using the available resources, and potentials. The mean of the (crisis management after the occurrence of the crisis) is high. That indicates that principals realize that they should benefit from the earlier experiences related to crisis management.

As for the third area (i.e. Crisis management in the light of the contemporary educational challenges), it is divided into three sub-areas. These sub-areas are: (ethical challenges, electronic challenges, and educational challenges).It was found that the mean of the (ethical challenges) is higher than the means of the other sub-areas. The mean of the (ethical challenges) is moderate. That may be attributed to the fact that these challenges emerged recently. Thus, it would be difficult for principals to address these challenges. Because these challenges emerged recently, principals shall not be able to realize how serious these challenges are.

The mean of the (electronic challenges) is moderate and ranked second. That indicates that principals and teachers realize the significance of using technology and application in the educational process. The latter mean is ranked second because there aren't many technology-related crises that have been experienced in the educational sector. That's because technology has been employed in educational institutions since a long time. Thus, teachers and principals show more acceptance today to the use of technology in education, though there are some barriers hindering such use.

As for the mean of (educational challenges), it is moderate and ranked last. That may be attributed to the detrainment of teachers and principals from acknowledging that the poor professional development of staff is hindering the educational process. If teachers and principals acknowledges that, it means that they are questioning their own potential and capabilities.

The results of the present study are consistent with the results of the study conducted by Liming (2010). The latter study sheds a light on the types of crises facing secondary schools. The results of the present study are inconsistent with the results of the studies conducted byHalaq (2011) and Battah (2016). The latter studies suggests that the extent of practicing crisis management by public secondary school principals is low. The results of the present study are inconsistent with the results of the study conducted by Cole (2010). The latter researcher aimed to explore the way the principals respond to crises.

As for the results of the second question, it was found that the significance levels of the areas of (practicing crisis management by Jordanian secondary school principals in the light of the contemporary educational challenges) are high.

In terms of significance, the mean of (the meaning of crisis management) is ranked first. In terms of significance, the mean of the (stages of crisis management and the principals' capability to manage crises) is ranked first too. In terms of significance, the mean of (crisis management in the light of the contemporary educational challenges) is high and ranked last. The mean of the significance of (the meaning of crisis management) is ranked first. The latter results may be attributed to the fact that it's difficult to manage any crises without realizing the meaning of crisis management and distinguishing between crises and other and other similar terms. Realizing such 
meaning shall enable principals to take the right administrative measures.

The mean of the significance of The area; (stages of crisis management and the principals' capability to manage crises) is divided into three sub-areas. It was found that the mean of the significance of (crisis management before the occurrence of the crisis) is higher than the means of the other sub-areas. The mean of the significance of (crisis management before the occurrence of the crisis) is high and ranked first. That indicates that principals realize that they should possess the administrative skills needed for avoiding and managing crises. Such skills may include: planning, organization, guidance and monitoring skills.

Regarding the mean of the significance of (crisis management during the occurrence of the crisis), it is high. It may be attributed to the fact that this stage is crucial. Thus, during this stage, principals must be capable to make decisions, form crisis management team, and communicate with the members of the community.

Regarding the mean of the significance of (crisis management after the occurrence of the crisis), it is high. The attention given by principals and teachers to this stage is attributed to the significance of this stage. To illustrate more, principals can't manage any future crisis without realizing the effectiveness of the existent plans in managing the crisis. In addition, following up the latest changes is just as important as assessing plans. It enables principals to manage crises in accordance with the requirements of the contemporary age.

The third area; (Crisis management in the light of the contemporary educational challenges) is divided into 3 sub-areas. It was found that the mean of the significance of (ethical challenges) is ranked first, followed by the mean of electronic and educational challenges respectively. The mean of the significance of (ethical challenges) is high. That may be attributed to the significance of these challenges and their impact on the educational process.

The mean of the significance of (electronic challenges) is high. That indicates that teachers and principals realize the seriousness of these challenges and their impact on the educational process. Enacting laws that regulate the use of electronic tools in educational institutions increased the awareness of principals about the seriousness of these

The mean of the significance of (educational challenges) is high. That may be attributed to the realization of the teachers and principals that refraining from handling these challenges shall generate many crises. Such challenges include: the ones related to teacher development.

The results related to the second question are consistent with the results concluded by Cole (2015). In the light of the aforementioned results, the researchers recommends the following:

1) Encouraging people to acknowledge the contemporary challenges and the crises that might be derived from such challenges.

2) Conducting similar studies in other Jordanian cities

3) Holding training courses and workshops for principals about the contemporary educational challenges

\section{References in Arabic language:}

- Abu Al-Ola, Layla (2012). The reality of crisis management in the public schools for females in Ta'if from the perspective of female supervisors. The Journal of the Faculty of Education. 28(3), 241-279

- Abu Farwa, Ibrahim Mohammad (1997). School administration. Tripoli, The Open University.

- Abu Naser, Mohammad Fathi (2008). Introduction to educational administration: Theories and skills. Amman. Dar Al-Maseera Publication and Distribution.

- Battah, Mansour Mushari (2016).A proposed vision for managing crises by public secondary school principals in Kuwait. Unpublished MA thesis. Al Al-Bait University. Mafraq. Jordan

- Al-Jahni, Abdullah Masoud (2010). Methods for making decisions to manage crises in schools from the perspective of school principals in Yanbu'. Unpublished MA thesis. King Aziz University. Jeddah, KSA

- Al-Habees, Khadeejah (2015). The strategies adopted by Jordanian public secondary school principals for managing crises and natural disasters: A case study in Qasabet Salt directorate of education. Unpublished PhD dissertation. Omdurman Islamic University. Sudan

- Al-Harbi, Waleed bin Nayef (2019). The social media platforms and their relationship with engagement in the community: A field study. Unpublished MA thesis. Naif Arab university for Security Sciences. KSA

- Hamdoonah, Hussam (2006). Practicing crisis management skills by secondary school principals in Gaza.Unpublished MA thesis. The Islamic University- Gaza. Palestine.

- Halaq, Mohammad (2011). The role of public secondary school principals in making plans for handling the educational crises: A field study in the schools located in Damascus. The Journal of Tishreen University for Scientific Studies and Research. The human sciences and art series. 33(3),181-198

- Al-Khazouz, Rula (2007). The development of an educational guide for managing crises in Jordanian secondary schools. Unpublished $\mathrm{PhD}$ dissertation. The University of Jordan. Amman. Jordan

- Al-Khudairi, Muhsen (2003). Crisis management: Cairo. Nile Group.

- Al-Khamees, Ibtisam (2019). The reality of making decisions by female secondary school leaders for 
managing crises in schools in Al-Qusaim. Unpublished MA thesis. Qusaim University. KSA

- Al-Khawaldeh, Tayseer and Al-Zyoodi, Majed (2012). The Jordanian educational system during the third millennium. Amman: Dar Al-Hamed Publication and Distribution.

- Zain Al-Deen, Mohammad (2013). The methods of developing a proposed future vision in scientific theses.

- Retrieved on 1/4/2012 from: http//www.faculty.psau.edu.com

- Al-Sharhan, Jamal (2000). Instructional tools and the latest changes in the field of educational technology.Reyad. Dar Al-Humaidifor Printing.

- Al-Tantawi, Mustafa (2000). Creating a program for developing scientific teachers in the faculties of education in the light of the challenges of the $21^{\text {st }}$ century. The Journal of the Faculty of Education. 5(23).43-60

- Odeh, Reham (2008). The reality of crisis management in the higher education institutions in Gaza: Empirical study in the Islamic University. Unpublished MA thesis. The Islamic University. Gaza. Palestine.

- Al-Musleehi, Mohammad Salem (1998). The awareness of university students about some recent challenges facing the Egyptian society. The Journal of the Faculty of Education. 7(75). 175-277

- The website of the Ministry of Education (2019). Retrieved on 1/4/2020 from http://www.moe.gov.jo

- Nataj, Fatema (2010). University and addressing the technological challenges. Cairo: Dar Al-Yosor publication and distribution.

- Al-Nawayseh, Reyad (2006). A proposed model for managing crises in the Ministry of Education in the light of the reality and the contemporary orientations. Unpublished $\mathrm{PhD}$ dissertation. Arab Amman University. Amman. Jordan

\section{References in English language}

- Chase, B(1999), Learning Bloody Lessons (Schools Shootings), National Education Association NEA,Today, Vol.17, No.7

- Cole, T. (2015). Evaluation of crisis Management Plan: An Analysis ofPrimary Schools in Jamaica , (unpublished thesis $\mathrm{Ph}$ ), Thomas university, Miami Gardens Florida.

- Devlin, E.S.(2007). Crisis Management Planning and Execution, CRC Press .London

- $\quad$ Liming , R, (2010). Stress sources and coping strategies of secondary public

- school principals, ( Un published doctoral ), university of Denver.

- Paterson, A. (2012). A study of the actual and Ideal task behaviours of the

- Arab private school principals in Jerusalem, (unpublished thesis Ph). . D,

- Ohio university . PSA. 